\title{
Cardiac Sarcoma
}

National Cancer Institute

\section{Source}

National Cancer Institute. Cardiac Sarcoma. NCI Thesaurus. Code C7723.

A malignant soft tissue neoplasm that arises from the heart. The majority of cases are angiosarcomas. 